\title{
Extended Technological Acceptance Model for Evaluating E-Learning: The African Context (ETAM-4EEA)
}

\author{
Martin Mabeifam Ujakpa and Delene Heukelman
}

\begin{abstract}
The Technological Acceptance Model (TAM) was developed in USA, which is culturally different from Africa. Due to the cultural differences and the Africa cultural diversity, applying the existing TAM to evaluate applications intended for use in Africa, might not produce good results. To accommodate cultural diversity, and in particular the African culture, relevant literature was reviewed and a mixed approach applied to collect and analyze data. The data were collected from 50 learners in five universities across five African regions (North, South, East, West and Central). The data were analyzed using Cronbach's $\alpha$ measure, Kaiser-Meyer-Olkin (KMO) measure, Bartlett's test of sphericity, confirmatory factor analysis (for each construct) and descriptive statistics (average mean and standard deviation). Based on results, an Extended Technological Acceptance Model was developed. The proposed model has four main constructs: Perceived Ease of Use (PEOU), Perceived Usefulness (PU), Perceived Performance (PP) and Benefits (B). Each of the constructs influence Behaviour Intention. Contrary to Davis, PEOU rated higher than PU: among the four constructs, PU rated the lowest. The study found that PEOU influnce PU: this confirms Davis findings. Considering that this study only developed a model, it is recommended that the model is tested using a number of information systems in Africa.
\end{abstract}

Keywords - African Context, Culture, E-learning, Technological Acceptance Model,

\section{INTRODUCTION}

By definition, culture is the belief of people towards human behavior and their relationships with reality: the way people live in a country, express their truths and values [6]. Dimensions of culture include individualism and collectivism. Individualism accepts the value that each person takes care of himself/herself before others and Collectivism accepts the value that a group places itself first before individuals [27].

Africa has 3000 distinct ethnic groups with 2000 languages (Africanholocaust, 2017) in 55 countries (African Union, 2018) and is home to the most genetically diverse people on Earth: diverse that two Africans are more genetically different from

M. M. Ujakpa is with Durban University of Technology, South Africa as a $\mathrm{PhD}$ Candidate and the International University of Management, Namibia as a Senior Lecturer and Faculty Dean. Previously he was with Ghana Technology University College, Accra Institute of Technology and Valley View University.

D Heukelman is with the Informatics Department of Durban University of Technology, South Africa..
Other (12). Technology Acceptance Model (TAM) has continuously been adapted and improved to be applied more widely, hence TAM3 is currently available [54], however, the uniqueness of the African cultures may pose a problem when TAM is applied in the African context . Applying TAM in Africa may not produce good results [42]. Transfer of TAM to different cultural context (except USA where it was originally developed) requires rigorous testing. [42] agree with this when they recommend that caution be taken when applying TAM in some countries and this may be because of cultural differences. Similarly, [57] and [35] point out that a deeper understanding of factors contributing to Ease of Use and Usefulness, two of the TAM constructs, is necessary. TAM neglects examination of different information systems and environments (cultural and social factors). TAM assumes that Technology use is at an individual level [57] and hence organizational level seem to be missing in.

A comparison by [55] indicate that TAM and the IS success model (ISSM) have strengths and weaknesses: while TAM gives detailed comprehensive on system use than the ISSM, ISSM evaluates the relationships between actual system usage, user satisfaction, and it's influence on overall impact (individual and Organization). In view of this, [55] proposed integration of the two to create a more comprehensive solid model. GETAMEL model on the other hand was developed based on most used external factors of TAM (experience, subjective norm, enjoyment, computer anxiety and self-efficacy) which seems not to cover information quality, system quality and service quality factors extensively [7].

TAM also assumes that technology use is by voluntary acts. Due to TAM's limitations, [30] recommended that an extended TAM is mandatory for any pre-implementation study of Information Communication Technology (ICT) among health workers in sub-Saharan Africa. To overcome TAM's limitations and implement [30] recommendation, [7] proposed a General Extended Technology Acceptance Model for e-Learning (GETAMEL) based on the commonly used external factors of TAM. Though their work was undertaken using samples from Africa, emphasis was not on the African context: instead, it was on the commonly used external factors of TAM in e-learning [7]. As a result, environmental factors (both cultural and social) are missing in GETAMEL.

Though TAM has widely been applied to various technological innovations globally and has successful predicted adoption behavior, it may not hold true in all cultures [42]. Since [7] work did not focus on the African context, 
GETAMEL may also not hold true in the African context. There is therefore the need to develop an extended TAM that takes into consideration the African context for evaluating quality, user satisfaction and acceptance of e-learning.

Considering the fact that TAM and GETAMEL may not hold true for all cultures [16] this study proposes an extended TAM, specifically for the African context, for evaluating quality, user satisfaction and acceptance of e-learning.

\section{LITERATURE REVIEW}

Several conclusions have been made on the impact of e-learning on learners. According to [21], learning management systems (e-learning) allow for longer-term access to training material and newer modules (containing current and relevant training material) for workshops to be developed to replace older modules and hence keep learners skills up to date, which could result in learners' performance and productivity being improved. According to [39], usage of e-learning ends in a significant positive impact on learners' academic accomplishments. Studies by [24] support [39] findings.

Like any technology, e-learning has critics. Issues raised by critics include quality, effectiveness and value addition. Critics question whether e-learning ensures quality, effectiveness and value addition in learning process ([31]; [37]). E-learning critics assert that in a face-to-face learning environment, physical cues are noticed by learners' and used to refine delivery mode: however, in e-learning physical cues are missing [31]. The study findings of [37] supports the findings of [31] that teaching certain courses through e-learning isn't appropriate.

The above discussion suggests that there are challenges regarding e-learning quality (compared to the traditional learning mode). One way to verify this is by measuring the perceived quality of e-learning and its effect on e-learning acceptance. Tools that can be used to examine perception and expectation of e-learning quality include $\operatorname{TAM}(1,2$ and 3$)$, Information Systems Success Model ([18]; [19]), Theory of Reasoned Action (Ajzen \& Fishein and Ajzen \& Fishein as cited by [49]), Cognitive Dissonance Theory (Anon, nd) and the TOE framework [5]. The most popularly used model is TAM.

Technology Acceptance Model (TAM), propounded by Davis as cited by [20], has two constructs (Perceived Usefulness-PU and Perceived Ease of Use-PEOU) that influence technology acceptance. The model propounds that these two factors influence an individual's belief in adopting information technology. Additionally, the theory has three other constructs: Attitude Towards Use (ATU), Intention to Use (IU) and Actual Usage (AU). PU and PEOU influence ATU and ATU influences IU and this in turn influences actual usage. Between PU and PEOU, [20], finds PU as the strongest influencer of IU. Davis, Bogozzi \& Warshaw (as cited by [35]) concluded that PU and PEOU are influenced by some external factors and hence modification on the original TAM as $\begin{array}{lllll}\text { demonstrated } & \text { in } & \text { Fig } & 1 & \text { below. }\end{array}$

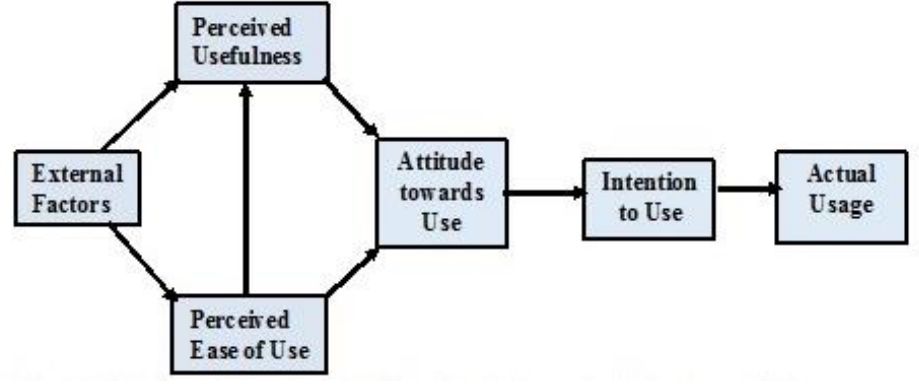

Fig 1: Technological Acceptance Model (Davis, Bagozzi and Warshaw as cited by [35])

Theory Reasoned Action (TRA), propounded by Fishbein \& Ajzen as cited by [49], models attitude-behavior relationships. The theory postulates that two factors (attitude and subjective norm) determines an individual's behavior intention. Some external factors (behavior belief, behaviour, evaluation normative norm and motivation to comply with the normative norm) influence these factors. Attitude influenced by behavior belief and behaviour evaluation. In other words, the belief about behaviour and its evaluation influence attitude, (Ajzen as cited by [49]). Subjective Norm is influenced by normative norm and motivation to comply with the normative norm. Fig 2 below is depicting theory of reasoned action.

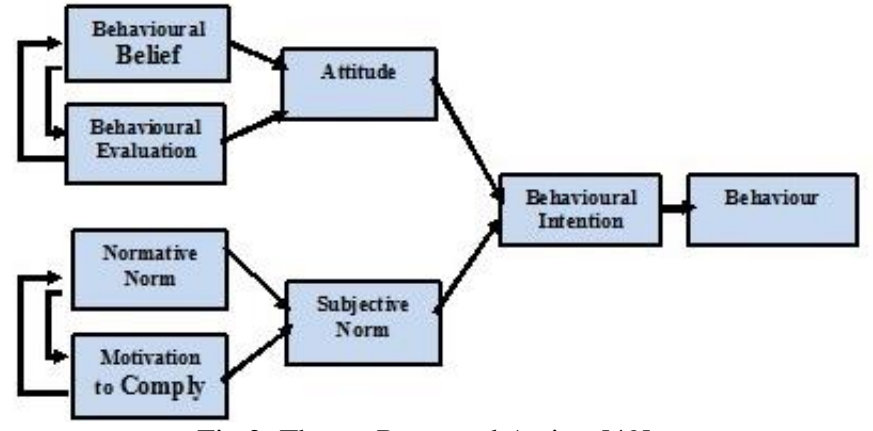

Fig 2: Theory Reasoned Action [49]

Information System Success Model (ISSM) postulated by [18] has six variables that make's an information system successful. These variables are system quality, information quality, use, user satisfaction, individual impact, and organizational impact. Fig 3 bellow depicts the ISSM model.

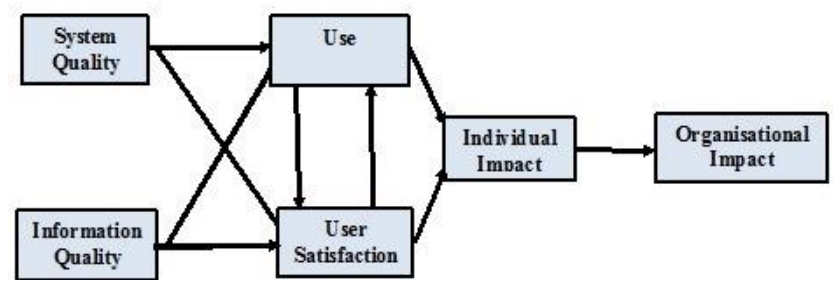

Fig 3: Information System Success Model [18]

TAM, ISSM and TRA relates to each other very much as they postulate factors on Technological Acceptance (TA). TAM, TRA and ISSM postulates Perceived Ease of Use (PEOU) \& Perceived Usefulness (PU), Attitude (Att) \& Subjective Norm (SN), System Quality (SystQ), Service Quality (ServQ) \& Information Quality (InfQual) as constructs for TA respectively. Using SystQ, infQ, ServQ \& User Satisfaction (UsS) from ISSM, Perceived Ease Of Use (PEOU) \& Perceived Usefulness (PU) from TAM1, voluntary \& experience from 
TAM3 and Subjective Norm (SN) from TRA, a semi structured interview guide was developed to aid in data collection for this study. The constructs above were chosen because they are the main constructs in the model or theory in which they are found.

\section{Methodology}

A Mixed methodology was applied for this study. To increase the value for the study and make it more representation, a wide range of research subjects from Africa was included in the study. The participants were chosen from public universities that have implemented e-learning system(s). One university was chosen from each region of Africa (North, South, East, West and Central).

Using semi structured interviews guide (developed from variables that constitutes the said variables above), data were gathered from 50 students in five universities: Durban University of Technology (South Africa, Southern Africa), Sudan University of Science and Technology (Sudan, Northern Africa), Kenyatta University (Kenya, East Africa), Federal University of Agriculture, Abeokuta (Nigeria, West Africa) and University évangélique en Afrique (DR Congo, Central Africa).

In each country, research assistants assisted in collecting the data. Though there is debate on the number of interviews needed to reach data saturation for themes in a survey research, the general rule-of-thumb is that, one choose as many subjects as possible for interviews until interviewee responses have reached saturation. This is confirmed by [60] who concluded from their research that 16 or fewer interviews were enough to identify common themes from sites with relatively homogeneous groups: however larger sample sizes: ranging from 20 to 40 interviews were needed when using interview as an instrument. Though larger sample sizes tend to be used for collecting quantitative information, there should always be a trade-off between the representativeness, diversity of a sample, efficiency and timeliness with which data can be collected [61] With above and considering the nature of this research, it was expected that responses would reach saturation by the time the researcher reaches the 50th interviewee and hence the choice of the sample size of 50. Due to the different e-learning market consumption size of each country [62] [63] as in Table I below, the sample was stratified as below and subjects chosen from each country as such.

\begin{tabular}{|c|c|c|c|c|}
\hline No & Region & Country & $\begin{array}{l}\text { E-learning } \\
\text { Market } \\
\text { Percentage }\end{array}$ & Sample \\
\hline 1 & $\begin{array}{c}\text { Southern } \\
\text { Africa }\end{array}$ & $\begin{array}{l}\text { South } \\
\text { Africa }\end{array}$ & $30 \%$ & 15 \\
\hline 2 & West Africa & Nigeria & $25 \%$ & 12 \\
\hline 3 & $\begin{array}{c}\text { Northern } \\
\text { Africa }\end{array}$ & Sudan & $20 \%$ & 10 \\
\hline 4 & East Africa & Kenya & $13 \%$ & 7 \\
\hline 5 & Central Africa & $\begin{array}{c}\text { DR } \\
\text { Congo } \\
\end{array}$ & $12 \%$ & 6 \\
\hline \multicolumn{3}{|c|}{ Total } & $100 \%$ & 50 \\
\hline
\end{tabular}

Source: (IT News Africa, 2016; Zealousys, 2017)

\section{ANALYSIS}

The data gathered were analyzed by assessing the semi-structured interview guide items. Reliability of the instrument was checked through Cronbach's $\alpha$ measure (item by item through model component). The sampling adequacy of analysis was checked using the Kaiser-Meyer-Olkin (KMO) measure and Bartlett's test of sphericity.

Though the sample has limitations (could be bigger, for a confirmatory factor analysis: but because interviews were conducted and the sample still fell within range), a confirmatory factor analysis was conducted. In addition, descriptive statistics (average mean and standard deviation) of each construct was calculated.

\section{RESULTS}

Results of the study is presented using a seven-column table as in Table II below. The first column consist of the various constructs. Corresponding variables to the constructs are in the second column. The third column represents the number $(\mathrm{N})$ of learners from who data was gathered. The fourth contains the Cronbach's $\alpha$ value. The Eigen Value \& Explained Variance(EV), KMO \& Bartlett's test, factor loading and average mean \& Standard Deviations are in the fifth, six and seventh columns respectively.

Data in Table II below enabled the researcher to verify whether the constructs proposed for the extended model correlate of not. The data was generated from the Cronbach's $\alpha$ measure of variables that formed the questionnaire. Of the 17 variables in the questionnaire, six correlated closely (with a Cronbach's $\alpha$ of 0.77 ) to form the Perceived Usefulness construct in the proposed model (fig 4). Four correlated closely (with a Cronbach's $\alpha$ of 0.82) to form the Perceived Ease of Use construct in the proposed model (fig 4). Another four correlated closely (with a Cronbach's $\alpha$ of 0.75) to form the Benefit construct in the proposed model (fig 4). The remaining variables (three) correlated closely (with a Cronbach's $\alpha$ of 0.70) to form the Perceived Performance construct in the proposed model (fig 4).

The construct rated highest is 'Perceived Ease of Use' with the highest average mean of 2.58 and a standard deviation score of 1.26. This indicates that experience on use of e-learning prior to using it, training on use of e-learning, e-learning information quality and students leading the process of teaching \& learning in an e-learning system enhances intention to accept and use e-learning systems.

Giving the fact that $50 \%$ of the questions for the construct 'Benefit' were reverse phrased, it follows that it rated low than Perceived Performance construct with an average mean of 1.94 and standard deviation of 0.79 . This indicates that influence by peers and important persons (referred to as subjective norm in literature), voluntary use and satisfaction are variables that account low for students' intention to accept and use e-learning systems. 'Perceived Usefulness rated lowest with the lowest average mean of 1.87 and a standard deviation score of 0.78 . This indicates that frequency of Use, System Quality and Satisfaction accounts lowest for technology acceptance in Africa. 
TABLE II: CONSTRUCTS, CRONBACH'S A, KMO, FACTOR LOADING, MEAN AND AVERAGE VALUES

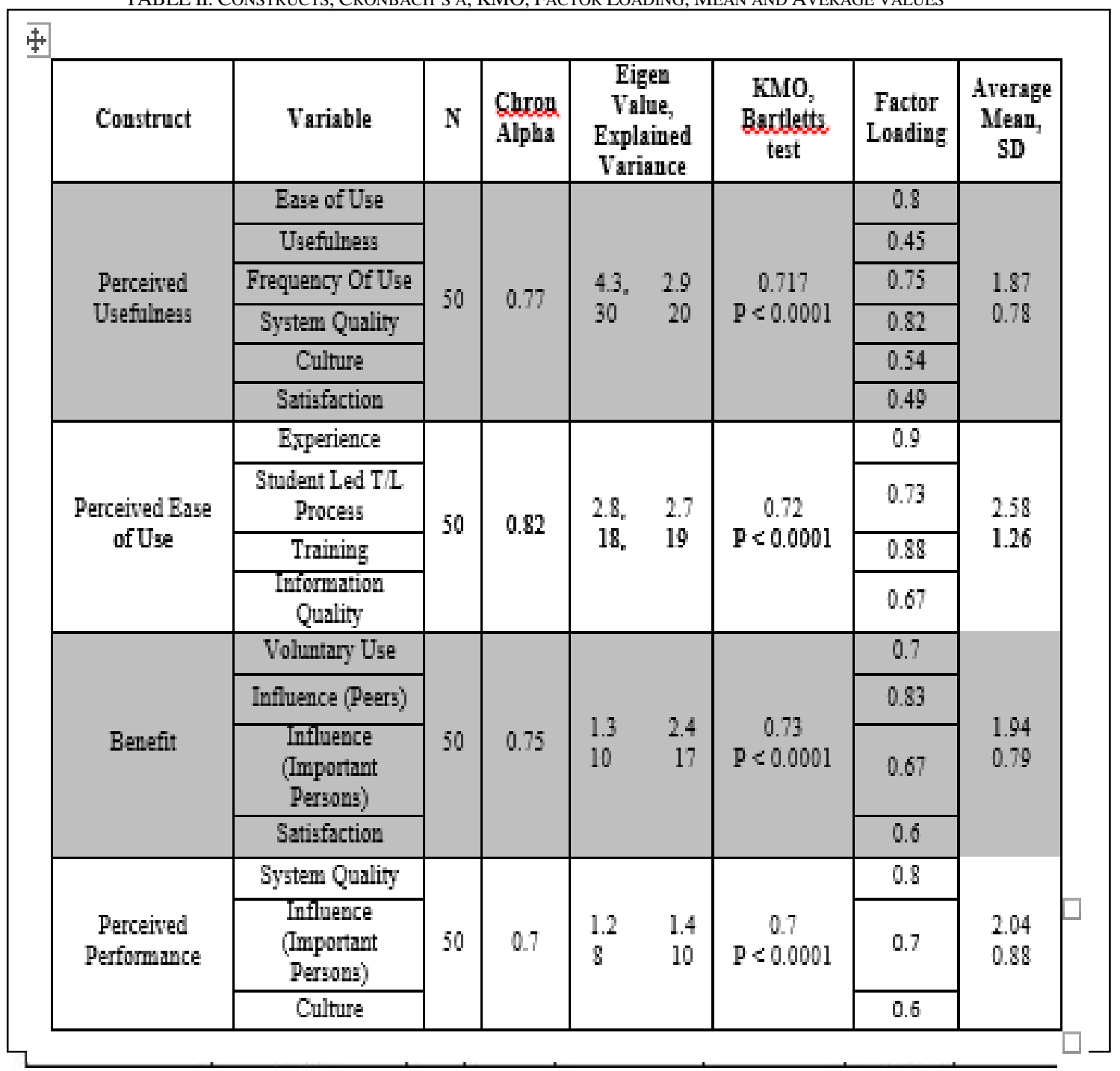

The construct 'Perceived Performance' was rated second highest with the average mean of 2.04 and a standard deviation of 0.88. This indicates that culture of Africa, system quality and influence by important persons enhances intention to accept and use e-learning systems. However, these variables enhances acceptance and use less than the variables in construct 'Perceived Ease of Use'. The variables, influence by important persons and system quality \& culture, sometimes even rated lower when compared other variables in construct 'Perceived Performance' as it rates equally like the variables in construct 'Benefit' (with an average mean of 1.34) or 'Perceived Usefulness' (with an average mean of 1.87) respectively.

Ease of Use, frequency of use and usefulness are variables that enhanced acceptance and use of e-learning system. The Construct (Perceived Usefulness) from which they emanate was rated an average mean of 1.87 and standard deviation of 0.78 . However, these variables enhances acceptance and use of e-learning than the variables in the constructs: Perceived Ease of Use and Perceived Performance. Fig 4 below is the developed extended TAM in the African context.

\section{DISCUSSION AND CONCLUSION}

The aim of this paper was to develop an extended TAM in the African context for evaluating quality, user satisfaction and acceptance of e-learning. As a result, five main constructs (made up of 13 variables) were identified from literature. The identified constructs are System Quality [18], Information Quality [18], Service Quality [19], Bahaviour Intention [49] and Actual Usage [20].

Results of the study indicated that the 13 variables obtained from literature to model the proposed extended TAM, correlated with each other: hence all 13 variables confirmed. Further analysis of the 14 variables resulted in four main constructs: Perceived Ease of Use, Perceived Usefulness, Perceived Performance and Benefits. Except Benefit, Each of these constructs influence Behaviour Intention directly. Hence in addition to the factors (PEOU and PU) postulated by (Davis, Bagozzi \& Warshaw as cited by [35]), Davis \& Venkatesh (2004) and Venkatesh \& Bala (2008), two additional factors (Perceived Performance and Benefit) that influences BI were established. Contrary to Davis (as cited in [20]) finding, 
Perceived Ease of Use rated higher than Perceived Usefulness. Perceived Ease of Use rated as the strongest influencer of Behaviour Intention, followed by Perceived Performance, then Benefit and Perceived Usefulness rated as the lowest influencer of Behaviour Intention. As in Davis (as cited in [20]) research findings, this study confirmed that Perceived Ease of Use influence Perceived Usefulness. Two factors and an additional variable that were identified from literature is Behaviour Intention, Actual Usage and External Factors respectively. The Extended TAM model below was generated.
In terms of factor analysis: though within range, the sample size was small. In future studies, a bigger sample size should be considered. Considering that this study developed the extended TAM in the African context, it is recommended that the model is tested using different information systems in Africa. Though data was collected from three different language (national official) speaking countries (English, French and Arabic), analysis was not carried out on the effect of Language on TAM. It is recommended that future studies consider analyzing the effect of language on TAM.

\section{RECOMMENDATION}

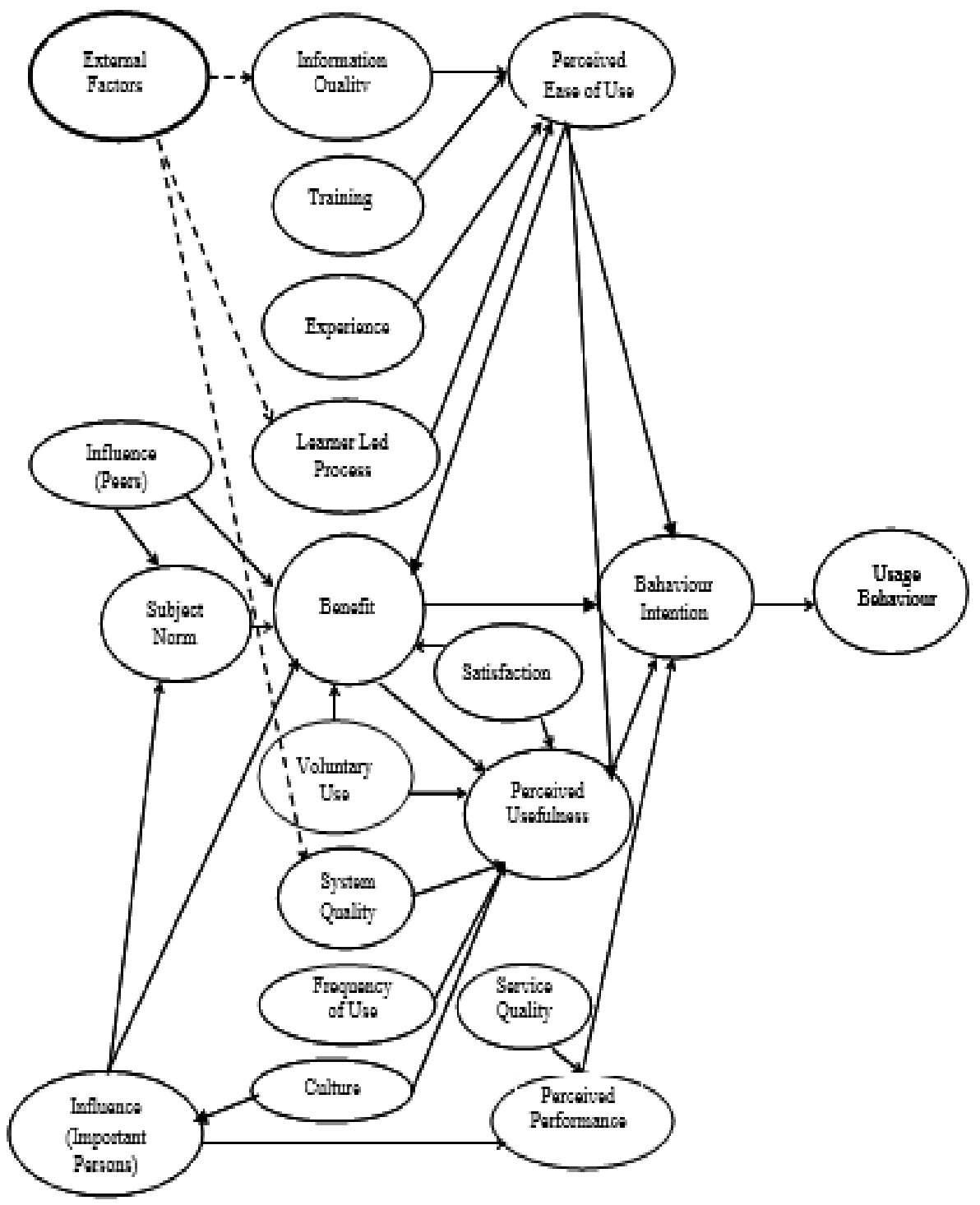

Fig 4: extended technological acceptance model in the African context 


\section{REFERENCES}

[1] Adekiya, A., A. (2016). Customer Loyalty in the Nigerian Telecommunication Industry: The Antecedence of Customer Satisfaction. International Journal of Independent Research Studies. Vol 3, Issue 1, Pp.22-48.

[2] Andrew, J., D. (2015). Testing the Technology Acceptance Model 3 (TAM 3) with the Inclusion of Change Fatigue and Overload, in the Context of Faculty from Seventh-day Adventist Universities: A Revised Model. Andrews University, Dissertations, paper 1581, p.9, Anon (nd). Cognitive Dissonance. Cognitive Dissonance. p2.

[3] African Union. (2018). History. African Union Handbook. Retrieved

from: https://au.int/sites/default/files/pages/31829-file-african_union_ha ndbook_2018_english-2.pdf

[4] African Holocaust. (2017). People of Africa. Retreived from: http://www.africanholocaust.net/peopleofafrica.htm

[5] Awa O. H., Ukoha O., Emecheta C. B. \& Liu S. (2016) Using T-O-E theoretical framework to study the adoption of ERP solution. Cogent Business \& Management, Vol 3, Issue 1, Pp1-23 https://doi.org/10.1080/23311975.2016.1196571

[6] Aparicio, M., Bacao, F \& Oliveira T. (2016). Cultural Impacts on E-learning Systems' Success. Internet and Higher Education, Vol 31, Pp.58-70. https://doi.org/10.1016/j.iheduc.2016.06.003

[7] Abdullah, F. \& Ward, R. (2016). Developing a General Extended Technology Acceptance Model for E-Learning (GETAMEL) by analysing commonly used external factors. Computers in Human Behavior, Vol 56. Pp.238-256. https://doi.org/10.1016/j.chb.2015.11.036

[8] Averweg, U., R. (2005). Applicability of the Technological Acceptance Model in Three Developing Countries: Saudi Arabia, Malaysia and South Africa. Alternation, Vol 12, Issue 1a, Pp.331-343.

[9] Al-gahtani, U., R. (2001). The Applicability of Technological Acceptance Model outside North America: An Empirical Test in the Arab World. BITWord 2001 Conference Proceedings, American University of Chicago, Egypt.

[10] Averweg, U., R. (2002). Executive Information System Usage: The Impact of Web Based Technologies. Master of Science Dissertation, Faculty of Science and Agriculture, University of Natal, Pietermaritzburg, South Africa.

[11] Anandarajan, M., Igbaria, M., Anakwe U., P. (2000). Technology acceptance in the banking industry: A perspective from a less developed country. Information Technology \& People, Vol 13, Issue 4, Pp.298-312 https://doi.org/10.1108/09593840010359491

[12] Africanholocaust. (2017). People of Africa. Retrieved from: http://www.africanholocaust.net/peopleofafrica.htm

[13] Bhat, T., H., \& Khan A., A. (2015). Cybercrimes, Security and Challenges. International Journal of Advanced Research in Computer and Communication Engineering, Vol 4, Issue 5, Pp.509 $-513$

[14] Basak, S. K., Wotto, M., Bélanger, P. (2017). Factors Affecting To E-Learning in Continuing Education in Africa: A Review of Literature. International Journal OF Engineering Sciences \& Management Research, Vol 4, Issue 1, Pp.86-97.

[15] Binyamin, S., Rutter, M. \& Smith, S. (2017). Factors Influencing the Students Use of Learning Management Systems: A case Study of King Abdulaziz University. Proceeding of the 12th International Conferencing on e-Learning, Pp289 - 297.

[16] Baptista, G., \& Oliveira, T. (2015). Understanding Mobile Banking: The Unified Theory of Acceptance and Use of Technology combined with Cultural Moderators. Computers in Human Behavior, Vol 50, Pp.418-430. https://doi.org/10.1016/j.chb.2015.04.024

[17] Creswell, J. W. (1998). Qualitative inquiry and research design: Choosing among five traditions. Thousand Oaks, CA: Sage Publications.
[18] DeLone, W. H., and McLean, E. R. (1992). Information Systems Success: The Quest for the Dependent Variable. Information Systems Research, Vol 3, Issue 1, Pp.60-69. https://doi.org/10.1287/isre.3.1.60

[19] Delone, W., H., \& Mclean, E., R. (2003). The DeLone and McLean Model of Information Systems Success: A Ten-Year Update. Journal of Management Information Systems, Vol 19, Issue 4, Pp.9-30

[20] Davis, F., D., \& Venkatesh, V. (2004). Toward Preprototype User Acceptance Testing of New Information Systems: Implications for Software Project Management. IEEE Transactions on Engineering Management, Vol 51, Issue 1, Pp.31-46. https://doi.org/10.1109/TEM.2003.822468

[21] Fasasi, R. O., \& Heukelman. D. (2017). ICT: Performance Evaluation of Community Development Worker's In South Africa on E-Skills. Information Technology for Development, Vol 23, Issue 2, Pp.388-402. https://doi.org/10.1080/02681102.2017.1283285

[22] Grifoll, J., et al. (2010). Quality Assurance of E-learning. ENQA held a workshop 14, Finland, Helsinki, P.45.

[23] Creswell, J. W. (1998). Qualitative inquiry and research design: Choosing among five traditions. Thousand Oaks, CA: Sage Publications. http://williamgodden.com/samplesizeformula.pdf

[24] Harandi, S., R. (2015) Effects of E-Learning on Students Motivation. Procedia - Social and Behavioral Sciences, Vol 181, Pp.423-430. https://doi.org/10.1016/j.sbspro.2015.04.905

[25] Huang, H. (2015). The Probability Model of Expectation Disconfirmation Process. Expert Journal of Marketing, Vol 3, Issue 1, Pp11-16.

[26] Hussein, A., A. (2016). Service Quality Practices and Customer Satisfaction in Taxi Companies in Nairobi. University of Nairobi, Kenya, Nairobi.

[27] Hofstede, G. (1984). Cultural Dimensions in Management and Planning. Asia Pacific Journal of Management, Vol 1, Issue 2, Pp.81-99. https://doi.org/10.1007/BF01733682

[28] Hofstede, G. (1995). Multilevel Research of Human Systems: Flowers, Bouquets and Gardens. Human Systems Management, Vol 14, P.207.

[29] IT News Africa. (2016). Africa's E-Learning Market Doubles to $\$ 500$ Million. IT News Africa. Retrieved from: http://www.itnewsafrica.com/2016/09/africas-e-learning-market-d oubles-to-500-million/

[30] Jimoh, L., Pate, M., A., Lin, L., \& Schulman, K., A. (2012). A Model for the Adoption of ICT by Health Workers in Africa. Int $J$ Med Inform. Vol 81, Issue 11. https://doi.org/10.1016/j.ijmedinf.2012.08.005

[31] Kaufman, W., T. (2015). Traditional vs. Electronic Learning Environment. Education and Human Development Master's Thesis, State University of New York, Paper 537, Pp1- 28. USA, New York.

[32] Kamaludin, K., \& Kamaludin, K., Z. (2017). User Acceptance of the Human Resource Information System: A Study of a Private Hospital in Malaysia. International Review of Management and Marketing, Vol 7, Issue 2, Pp.207-217.

[33] Lai, P. C. (2017). The Literature Review of Technology Adoption Models and Theories for the Novelty Technology. Journal of Information Systems and Technology Management, Vol 14, Issue 1, Pp21-38. https://doi.org/10.4301/S1807-17752017000100002

[34] Lodhia, R. (2006). Annotated Bibliography On E-Learning And Application Of Educational Technology In African Countries Or In Context Relevant To Africa. Carnegie Corporation, USA, New York.

[35] Lee, Y., Kozar, K., A., \& Larsen, K., R., T. (2003). The Technology Acceptance Model: Past, Present, and Future. Communications of the Association for Information Systems, Vol 12, Issue 50, Pp.752-780. https://doi.org/10.17705/1CAIS.01250

[36] Leidner, D. E., \& Kayworth, T. (2006). Review: A Review of Culture in Information Systems Research: Toward a Theory of 
Information Technology Culture Conflict. MIS Quarterly, Vol 30, Issue 2, Pp357-399.

https://doi.org/10.2307/25148735

[37] Mamattah, R., S. (2016). Students Perception of E-Learning. Linkoping University, Sweden, Linkoping

[38] Miller, S., L. (2015). Teaching On Online Pedagogy MOOC. MERLOT Journal of Online Teaching and Leaning, Vol 11, Issue 1, Pp. $104-119$.

[39] Mothibi, G. (2015). A Meta-Analysis of the Relationship between E-Learning and Students Academic Achievement in Higher Education. Journal of Education and Practice, Vol 6, Issue 9, Pp.6-9.

[40] Mugica, A., (2015). The Case of Election Technology. Springer European View, Vol 14, Pp.111-119. https://doi.org/10.1007/s12290-015-0355-5

[41] Nazwirman, S. \& Kom, M., M. (2015). The Influence of Perceived Service Performance and Price Fairness towards Repurchase through Customer Satisfaction and Word of Mouth: An empirical Study of Lion Air Company, International Journal of Advanced Research, Vol 3, Issue 10. Pp. 1846-1854.

[42] McCoy, S., Galletta, D., F., \& King, W., R. (2007). Applying Tam across Cultures: The Need for Caution. European Journal of Information System, Vol 16, Issue 1, Pp.81-90. https://doi.org/10.1057/palgrave.ejis.3000659

[43] Morse, J. M. (1994). Designing funded qualitative research. In Denizin, N. K. \& Lincoln, Y. S., Handbook of qualitative research (2nd Ed). Thousand Oaks, CA: Sage.

[44] Ojo, A., I. (2017). Validation of the DeLone and McLean Information Systems Success Model. Healthcare Informatics Research, Vol 23, Issue 1, Pp.60-66. https://doi.org/10.4258/hir.2017.23.1.60

[45] Oliver, R., L. (1980). A Cognitive Model of the Antecedents and Consequences of Satisfaction Decisions. Journal of Marketing Research, Vol 17, Issue 4, Pp.460-469. https://doi.org/10.2307/3150499

[46] Onyeaso, G., \& Adalikwu, C. (2008). An empirical test of customer retention-perceived quality link: strategic management implications. Journal of Business Strategy, Vo 25, Issue 1, Pp.53-71.

[47] Perez-Alveen, C. (nd). Uncertainty avoidance, IT Perception, Use and Adoption: Distributed teams in two cultures. AABRI journal, Pp.1-8.

[48] Rarick, C., Winter, G., Nickerson, I., Falk, G., Barczyk, C. \& Asea P. K. (2013). An Investigation of Ugandan Cultural Values and Implications for Managerial Behavior. Global Journal of Management and Business Research Administration and Management, Vol 13, Issue 9.

[49] Southey, G. (2011). The Theories of Reasoned Action and Planned Behaviour Applied to Business Decisions: A Selective Annotated Bibliography. Journal of New Business Ideas \& Trends, Vol 9, Issue 1, Pp.43-50.

[50] Saeed, F., Gazen, N., Patnaik, S., Balaid, A. S. S. \& Mohammed, F. (2017). Recent Trends in Information and Communication Technology: Lecture Notes on Data Engineering and Communication Technology. Proceedings of the 2nd International Conference of Reliable Information and Communication Technology: Springer, P.689. https://doi.org/10.1504/IJICT.2017.082080

[51] Suradi, Z. (2001). Testing Technology Acceptance Model in Malaysian Environment. BIT Conference Proceedings, American University of Chicago, Egypt.

[52] L. G. Tornatzky, M. Fleischer, and A. K. Chakrabarti (1990), the processes of technological innovation. Lexington Books.

[53] UNESCO. (2016). Blended Learning for Quality Higher Education: Selected Case Studies on Implementation from Asia-Pacific. Retrieved from: http://creativecommons.org/licenses/by $\mathrm{sa} / 3.0 /$ igo/)

[54] Venkatesh, V., \& Bala, H. (2008). Technology Acceptance Model 3 and a Research Agenda on Interventions. Decision sciences, Vol 39, Issue 2, Pp.273-315. https://doi.org/10.1111/j.1540-5915.2008.00192.x
[55] Wang, W. T., and Liu, C. H. (n.d.). The application of the technology acceptance model: A new way to evaluate Information System Success. Albany, NY: School of 258 Information Science and Policy, University at Albany.

[56] WHO. (2015). E-LEARNING for undergraduate health professional education - a systematic review informing a radical transformation of health workforce development. Switzerland.

[57] Woraporn, R., \& Seung, K. (2002). A Framework to Study Technology Use: Alternatives to Technology Acceptance Model. Americas Conference on Information Systems, Proceedings 127, Pp.883-889. Retrieved from: http://aisel.aisnet.org/amcis2002/127

[58] Zangmo, M., Liampreecha, W., \& Chemsripong, S., (2015). The Impact of Service Quality on Customer Retention in Airline Industry in Bhutan. International Business Management, Vol 9, Issue 6, Pp.1281-1284

[59] Zealousys. (2017). E-Learning Trends in Africa. Zealous Systems. Retrieved from: http://www.zealousys.com/blog/e-learning-trends-africa-2017/

[60] Hagaman A. K. \& Wutich A. (2017). How Many Interviews Are Enough to Identify Metathemes in Multisited and Cross-cultural Research? Another Perspective on Guest, Bunce, and Johnson's (2006) Landmark Study. Field Methods, Vol 29, Issue 1, Pp23-41 https://doi.org/10.1177/1525822X16640447

[61] ACAPS. (2011). Technical Brief on Sampling and Site Selection. Retrieved from: http://www.parkdatabase.org/files/documents/120216_tb_samplin g_and_site_selection_final.pdf

[62] IT News Africa. (2016). Africa's E-Learning Market Doubles to $\$ 500$ Million. IT News Africa. Retrieved from: http://www.itnewsafrica.com/2016/09/africas-e-learning-market-d oubles-to-500-million/

[63] Zealousys. (2017). E-Learning Trends in Africa. Zealous Systems. Retrieved from: http://www.zealousys.com/blog/e-learning-trends-africa-2017/ 